\title{
PENINGKATAN PRODUKSI TELUR IKAN NILEM (Osteochilus hasselti CV) MELALUI TERAPI HORMON DAN NUTRISI
}

\section{INCREASING PRODUCTION OF FISH EGGS NILEM (Osteochilus hasselti CV) THROUGH THE HORMONE THERAPY AND NUTRITION}

\author{
Radhi Fadhillah, \\ Jurusan Akuakultur Fakultas Perikanan dan Ilmu Kelautan Universitas Teuku Umar \\ Korespondensi: radhifadhillah@utu.ac.id
}

\begin{abstract}
ABSTRAK
Penelitian ini bertujuan untuk mengevaluasi pengaruh kombinasi hormon Oodev (Oocyte Development) dan rGH (recombinant growth hormone) serta nutrisi dengan suplementasi minyak ikan kedalam pakan terhadap peningkatan produksi telur pada ikan nilem (Osteochilus hasselti). Rancangan penelitian yang digunakan adalah rancangan acak lengkap dengan lima perlakuan dan 20 ekor ulangan individu. Perlakuan yang diterapkan yaitu: OMiGH (Oodev $1 \mathrm{~mL} \mathrm{~kg}^{-1} \mathrm{ikan}+\mathrm{rGH}$ $0,1 \mathrm{mg} \mathrm{kg}^{-1}$ ikan+MI $30 \mathrm{~g} \mathrm{~kg}^{-1}$ pakan); OMi (Oodev $1 \mathrm{~mL} \mathrm{kg-1} \mathrm{ikan+MI} 30 \mathrm{~g} \mathrm{~kg}^{-1}$ pakan); OGH (Oodev $1 \mathrm{~mL} \mathrm{kg-1}$ ikan+rGH 0,1 mg kg-1 ikan); GHMi (rGH 0,1 mg kg-1 ikan+MI $30 \mathrm{~g} \mathrm{~kg}^{-1}$ pakan); dan Kontrol (Pakan Komersil). Bobot ikan nilem yang digunakan yaitu $135 \pm 27,25 \mathrm{~g} \mathrm{ekor}^{-1}$ dipelihara selama 42 hari dalam hapa berukuran $2 \times 2 \times 2 \mathrm{~m}$ dengan kepadatan 20 ekor hapa $^{-1}$. Pakan diberikan sebanyak tiga kali sehari yaitu jam 07.00, 12.00 dan 17.00 WIB dengan feeding rate pakan sebesar 3\%. Hasil penelitian menunjukkan bahwa perlakuan OMiGH merupakan perlakuan terbaik karena dapat meningkatkan persentase pertumbuhan gonad mencapai $73,03 \%$ dari pertambahan bobot tubuh sebesar $60,33 \pm 11,87 \mathrm{~g}$. Selain itu, dapat meningkatkan produksi telur dilihat dari nilai gonadosomatik indeks (GSI) dan fekunditas sebesar 23,56\% dan 290265 butir ekor $^{-1}$ lebih tinggi dibandingkan kontrol.
\end{abstract}

Kata kunci: Osteochilus hasselti, Oodev, rGH, minyak ikan, produksi telur

\begin{abstract}
This study was aimed to evaluate the effect of Oodev (oocyte Development) combined hormone and recombinant growth hormone $(\mathrm{rGH})$ as well as nutritional factor through fish oil supplementation added in nilem (Osteochilus hasselti C.V) diet to increasing egg production. The experimental design was arrange in completely randomize design with five treatments and 20 fishes as replications. The applied treatment were: OMiGH $\left(1 \mathrm{~mL}\right.$ Oodev kg${ }^{-1}$ fish $+\mathrm{rGH} 0.1 \mathrm{mg}$ $\mathrm{kg}^{-1}$ fish + fish oil $30 \mathrm{~g} \mathrm{~kg}^{-1}$ feed); OMI (1 mL Oodev kg-1 fish + fish oil $30 \mathrm{~g} \mathrm{~kg}^{-1}$ feed); OGH (1 mL Oodev kg-1 fish + rGH $0.1 \mathrm{mg} \mathrm{kg}^{-1}$ fish); GHMi (rGH $0.1 \mathrm{mg} \mathrm{kg}^{-1}$ fish + fish oil $30 \mathrm{~g} \mathrm{~kg}^{-1}$ feed); and Control treatment (commercial diet). Fishes with initial body weight $135 \pm 27.25 \mathrm{~g}^{\text {individual }}{ }^{-1}$ maintained for 42 days in net cage sized $2 \times 2 \times 1 \mathrm{~m}$ filled by 20 fish net cage ${ }^{-1}$ in density. Fishes were fed three times daily at $07.00 \mathrm{am}, 12.00 \mathrm{pm}$ and $17.00 \mathrm{pm}$ with $3 \%$ feeding rate. The results showed $\mathrm{OMiGH}$ was the best treatment to increase the percentage of nilem gonadal development as high as $73.03 \%$ of body weight for $60,33 \pm 11,87 \mathrm{~g}$. Furthermore, OMiGH could be increased egg production seen by gonadosomatic index (GSI) value up to $23.56 \%$ and fecundity as much as 290265 egg grains of fish ${ }^{-1}$ higher than the control tretament.
\end{abstract}

Keywords: Osteochilus hasselti, Oodev, rGH, Fish Oil, Egg Production

Fakultas Perikanan dan Ilmu Kelautan, Universitas Teuku Umar

Korespondensi : Jurusan Akuakultur, Fakultas Perikanan dan Ilmu Kelautan, Universitas Teuku Umar, Kampus UTU Meulaboh, Alue Peunyareng 23615, Telp: +62 81360272409, email: radhifadillah@utu.ac.id 


\section{PENDAHULUAN}

Ikan nilem (Osteochilus hasselti) merupakan salah satu spesies ikan air tawar asli Indonesia yang telurnya digemari masyarakat, karena memiliki cita rasa yang lezat serta berpeluang dijadikan pengganti kaviar dari ikan sturgeon (Acipencer sturio dan Acipencer huso) (Subagja et al., 2007). Beberapa aspek yang menyebabkan ikan nilem berpotensi dijadikan kaviar yaitu berat gonad dapat mencapai $18-26 \%$ dari berat tubuhya (Dewi dan Soeminto, 2005). Tingkat kematangan gonad ikan nilem lebih cepat dibandingkan ikan sturgeon (A. sturio). Masa kematangan gonad ikan nilem untuk dapat menghasilkan telur dicapai pada umur 1-1,5 tahun sedangkan ikan sturgeon selama 14 tahun. Selain itu, masa rematurasi yang dibutuhkan ikan nilem hanya selama 3 bulan (Novianto, 2013).

Peningkatan produksi telur sangat erat kaitannya dengan proses kecepatan pematangan gonad ikan. Metode peningkatan kematangan gonad secara hormonal merupakan salah satu metode yang efektif. Oodev merupakan hormon yang mengandung pregnant mare serum gonadotropin (PMSG) dan antidopamin. Beberapa penelitian telah membuktikan kinerja dari hormon ini dalam meningkatkan kematangan gonad. Penelitian Farastuti (2014) menunjukkan bahwa, induksi hormon Oodev sebanyak $0,5 \mathrm{~mL} \mathrm{~kg}^{-1}$ bobot ikan dapat mempercepat kematangan gonad ikan tor soro dalam waktu 2 minggu. Penyuntikan Oodev sebesar $10 \mathrm{IUkg}^{-1}$ induk ikan nila dapat meningkatkan kinerja hasil reproduksi ikan nila mencapai $300 \%$ dan meningkatkan fekunditas telur sebesar 2065 butir ekor-1 (200 g) (Rahmatia, 2013). Hasil penelitian Nainggolan et al.(2014) melaporkan, suplementasi Spirulina platensis sebanyak 3\% dan penyuntikan Oodev 15 IU $\mathrm{kg}^{-1}$ dapat meningkat kematangan gonad dan meningkatkan fekunditas ikan lele (Clarias sp.) sebesar 48953 butir $\mathrm{kg}^{-1}$.

Secara endokrinologi pertumbuhan dan reproduksi sangat erat kaitannya pada hewan vertebrata, hal ini disebabkan oleh hubungan timbal balik di sumbu neuroendokrin dalam mengendalikan hormon pertumbuhan dan reproduksi (Hull \& Harvey 2002; Cao et al. 2014). Menurut Sirotkin (2005), hormon GH (growth hormone) dapat digunakan untuk meningkatkan reproduksi (spermatogenesis dan oogenesis, ovulasi, perkembangan embrio, dan kelangsungan hidup). Akan tetapi, ketersediaan GH endogenous yang terdapat pada ikan sangat sedikit dan terbatas (Won \& Borski 2013). Untuk mengatasinya, dapat memanfaatkan rGH (GH eksogenous) yang menunjukkan fungsi yang sama dengan GH endogenous (Acosta et al. 2007). Muhammad (2014) melaporkan bahwa, penambahan hormon rEIGH sebanyak $3 \mathrm{mg}$ $\mathrm{kg}^{-1}$ dapat meningkatkan gonadosomatik indeks (GSI) pada ikan nila(Oreochromis niloticus) strain SULTANA sebesar 3,98\% dibanding kontrol $(\mathrm{P}<0.05)$.

Asam lemak esensial berasal dari minyak ikan mempunyai peran penting terhadap penampilan reproduksi ikan baik untuk pembentukan gonad maupun pematangan gonad. Penelitian-penelitian yang telah dilakuan menunjukkan peran minyak ikan dalam proses reproduksi antara lain mampu meningkatkan fekunditas pada telur ikan nila (Oreochromis niloticus) (Darwisito, 2008; Keong \& Wang 2011), mampu meningkatkan produksi telur pada ikan baung (Ictalurus punctatus) (Sink et al., 2010), mampu mempercepat perkembangan gonad pada ikan bayam-bayam (Scatophagus argus) (Zhang et al., 2013) dan mampu mempercepat kematangan gonad pada udang lobster air tawar (Procambarus clarkii) (Wang et al., 2011). Berdasarkan hal tersebut, maka dibutuhkan suatu kajian untuk meningkatkan produksi telur ikan nilem melalui teknik terapi hormon Oodev dan rGH serta penambahan nutrisi minyak ikan kedalam pakan.

\section{METODE PENELITIAN}

Penelitian ini dilaksanakan selama 4 bulan bertempat di Balai Besar Perikanan Budidaya Air Tawar (BBPBAT) Sukabumi. Analisis hormon dilakukan di Laboratorium Fakultas Kedokteran Hewan Universitas Syiah Kuala sedangkan analisis proksimat dilakukan di Laboratorium Terpadu Institut Pertanian Bogor. Penelitian ini menggunakan metode eksperimental rancangan acak lengkap (RAL) dengan lima perlakuan dan 20 ekor ulangan individu. Data yang diperoleh ditabulasi dan dianalisis menggunakan program excel 2007 dan SPSS V.16.0. Perlakuan yang berbeda nyata akan diuji lanjut dengan uji lanjut Duncan 
Pembuatan Pakan Mengandung Oodev, rGH dan Minyak Ikan

Pakan yang digunakan yaitu pakan komersial berbentuk pelet. Hormon yang digunakan dalam penelitian ini yaitu Oodev (Oocyte Development) dan recombinant growth hormon $(\mathrm{rGH})$ serta nutrisi yang ditambahkan kedalam pakan yaitu minyak ikan. Peningkatan nutrisi dalam pakan digunakan minyak ikan. Dosis hormon yang digunakan dalam penelitian yaitu Oodev $1 \mathrm{~mL}$ $\mathrm{kg}^{-1}$ ikan, $\mathrm{rGH} 0,1 \mathrm{mg} \mathrm{kg}^{-1}$ ikan dan minyak ikan $30 \mathrm{~g} \mathrm{~kg}^{-1}$ pakan. Pelarut hormon oodev dan $\mathrm{rGH}$ digunakan larutan $\mathrm{NaCl}$, sedangkan pelarut minyak ikan yang digunakan yaitu larutan etanol. Perlakuan yang diterapkan pada penelitian ini yaitu: OMiGH (Oodev +Minyak Ikan+rGH); OMi (Oodev+Minyak Ikan); OGH (Oodev+rGH); GHMi (rGH+Minyak Ikan); Kontrol (Pakan Komersil).

Metode pembuatan pakan perlakuan dilakukan dalam 2 tahap. Tahap pertama pencampuran minyak ikan dengan larutan etanol, kemudian disemprot pada pakan selanjutnya dikering anginkan. Tahap kedua yaitu pencampuran hormon dengan larutan fisiologis kemudian ditambahkan putih telur (binder) sebanyak 1 butir $\mathrm{kg}^{-1}$ pakan dan selanjutnya disemprotkan pada pakan. Pakan yang telah dicampur minyak ikan dan hormon tersebut dikering anginkan. Pembuatan pakan ini dilakukan 2 minggu sekali.

Ikan nilem yang digunakan dalam penelitian ini yaitu ikan nilem betina dengan ukuran berkisar $135 \pm 27,25 \mathrm{~g}$ yang berasal dari kolam Balai Besar Perikanan Budidaya Air Tawar (BBPBAT) Sukabumi. Ikan selama penelitian dipelihara dalam hapa yang berukuran $2 \times 2 \times 1 \mathrm{~m}$ dengan kepadatan 20 ekor hapa ${ }^{-1}$. Pemberian pakan selama penelitian diberikan sebanyak tiga kali sehari yaitu pukul 07.00, 12.00 dan 17.00 WIB dengan feeding rate pakan sebesar $3 \%$.

\section{Parameter yang diamati}

Parameter yang diamati terdiri dari pertambahan bobot (somatik dan gonad), Gonadosomatic Indeks (GSI), fekunditas (jumlah telur dalam ovari) dan diameter telur.

\section{HASIL DAN PEMBAHASAN}

Hasil pengamatan pertambahan bobot ikan tertinggi selama penelitian terdapat pada perlakuan OMiGH sebesar 60,33 $\mathrm{g}_{\text {ekor }}{ }^{-1}$ dan terendah terdapat pada perlakuan kontrol sebesar 55,85 g ekor-1 (Tabel 1). Hal ini menunjukkan bahwa penambahan hormon oodev, rGH dan minyak ikan kedalam pakan berpengaruh nyata terhadap peningkatan pertambahan bobot ikan dibanding dengan perlakuan kontrol $(\mathrm{P}<0,05)$.

Pertambahan bobot ikan selama pemeliharaan terbagi atas pertumbuhan gonad dan pertumbuhan somatik (tubuh). Persentase bobot gonad tertinggi terdapat pada perlakuan OMiGH sebesar $73,03 \%$ dari pertambahan bobot ikan sebesar 60,33 g ekor-1 dan persentase gonad terendah terdapat pada perlakuan kontrol sebesar $55,85 \%$ dari pertambahan bobot ikan sebesar 47,00 g ekor-

${ }^{1}$. Berdasarkan data tersebut dapat diketahui bahwa pengaruh penambahan hormon oodev, rGH dan minyak ikan ke dalam pakan dapat meningkatkan pertumbuhan gonad lebih tinggi dibandingkan pertumbuhan somatik pada ikan nilem.

Analisis pengamatan nilai GSI selama penelitian disajikan pada Gambar 1. Hasil analisis menunjukkan bahwa perlakuan OMiGH dan OMi mengalami peningkatan optimal sampai hari ke-28, namun pada perlakuan OGH, GHMi dan kontrol masih mengalami peningkatan nilai GSI sampai hari ke-42.

Peningkatan nilai GSI tertinggi pada hari ke-28 terdapat pada perlakuan OMiGH sebesar $23,56 \%$ dan terendah terdapat pada perlakuan kontrol sebesar $10,67 \%$. Hal ini menunjukkan penambahan hormon oodev, $\mathrm{rGH}$, dan minyak ikan dapat memacu peningkatan kematangan gonad lebih cepat dibanding kontrol. Hari ke-42 menunjukkan terjadinya penurunan nilai GSI pada perlakuan OMiGH dan OMi. Nilai GSI tertinggi pada hari ke-42 terdapat pada perlakuan OGH sebesar 25,30\% dan 15,92\%, namun terjadinya penurunan nilai GSI pada perlakuan $\mathrm{OMiGH}$, OMi dan $\mathrm{OGH}$ sebesar $21,28 \%, 20,99 \%$ dan $17,02 \%$.

Hasil pengamatan fekunditas (jumlah telur) selama penelitian disajikan pada Tabel 2. Fekunditas tertinggi pada hari 28 terdapat pada perlakuan $\mathrm{OMiGH}$ yaitu sebesar $290625 \pm 78608$ butir $\mathrm{kg}^{-1}$ dan perlakuan 
terendah terdapat pada perlakuan kontrol sebesar $123525 \pm 15652$ butir kg-1.

Tabel 1. Pertambahan bobot Ikan Nilem selama pemeliharaan (Gonad dan Somatik)

\begin{tabular}{lccc}
\hline Perlakuan & $\begin{array}{c}\text { Pertambahan Bobot } \\
\left(\mathbf{g ~ e k o r}^{-\mathbf{1}}\right)\end{array}$ & $\begin{array}{c}\text { Gonad } \\
(\boldsymbol{\%})\end{array}$ & $\begin{array}{c}\text { Somatik } \\
(\boldsymbol{\%})\end{array}$ \\
\hline OmiGH & $60,33 \pm 11,87^{\mathrm{b}}$ & 73,03 & 26,97 \\
Omi & $45,35 \pm 12,62^{\mathrm{a}}$ & 71,22 & 28,78 \\
OGH & $48,67 \pm 17,57^{\mathrm{a}}$ & 65,37 & 34,63 \\
GHMi & $42,14 \pm 10,50^{\mathrm{a}}$ & 64,60 & 35,40 \\
$\mathrm{~K}$ & $47,00 \pm 14,49^{\mathrm{a}}$ & 55,85 & 44,45
\end{tabular}

Keterangan: superskrip yang berbeda pada kolom yang sama menunjukkan perbedaan yang nyata antara perlakuan $(\mathrm{P}<0,05)$.

Tabel 2. Fekunditas Telur Ikan Nilem Selama Pemeliharaan

\begin{tabular}{lcc}
\hline \multirow{2}{*}{ Perlakuan } & \multicolumn{2}{c}{ Fekunditas Telur $\left(\mathbf{b u t i r}_{\mathbf{~ k g}^{-1}}\right)$} \\
\cline { 2 - 3 } & Hari ke-28 & Hari ke-42 \\
\hline OMiGH & $290265 \pm 78608^{\mathrm{c}}$ & $220140 \pm 64676^{\mathrm{ab}}$ \\
Omi & $248052 \pm 44255^{\mathrm{bc}}$ & $227744 \pm 18077^{\mathrm{ab}}$ \\
OGH & $165958 \pm 15387^{\mathrm{ab}}$ & $266517 \pm 8134^{\mathrm{b}}$ \\
GHMi & $205614 \pm 21587^{\mathrm{ab}}$ & $217187 \pm 6924^{\mathrm{ab}}$ \\
K & $123525 \pm 15652^{\mathrm{a}}$ & $175129 \pm 8644^{\mathrm{a}}$ \\
\hline
\end{tabular}

Keterangan: superskrip yang berbeda pada kolom yang sama menunjukkan perbedaan yang nyata $(\mathrm{P}<0,05)$ antara perlakuan. OMiGH (Oodev + Minyak Ikan + rGH); OMi (Oodev + Minyak Ikan); OGH (Oodev + rGH); GHMi (rGH + Minyak Ikan); dan K (Kontrol).

Pengamatan pada hari ke 42 menunjukkan perlakuan $\mathrm{OMiGH}$ dan $\mathrm{OMi}$ mengalami penurunan nilai fekunditas. Fekunditas tertinggi pada hari 42 terdapat pada perlakuan OGH sebesar $266517 \pm 8134$ butir $\mathrm{kg}^{-1}$ dan terendah terdapat pada perlakuan kontrol sebesar $175129 \pm 8644$ butir $\mathrm{kg}^{-1}$. Berdasarkan uji statistik menunjukkan penambahan oodev, rGH dan minyak ikan
(OMiGH) kedalam pakan dapat memberikan pengaruh nyata terhadap fekunditas telur dibanding dengan kontrol $(\mathrm{P}<0.05)$.

Pertumbuhan ikan terbagi atas dua jenis, yaitu pertumbuhan somatik (tubuh) dan pertumbuhan gonad. Hasil pengamatan

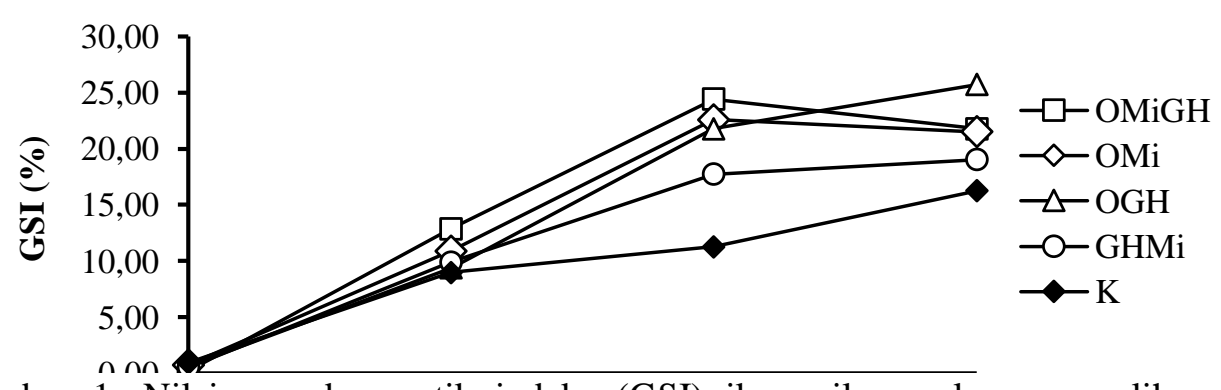

Gambar 1. Nilai gonadosomatik indeks (GSI) ikan nilem selama pemeliharaan. OMiGH (Oodev+Minyak Ikan+rGH); OMi (Oodev+Minyak Ikan); OGH (Oodev+rGH); GHMi (rGH+Minyak Ikan); dan K (Kontrol) 
menunjukkan bahwa adanya pengaruh penambahan hormon oodev, rGH, dan minyak ikan ke dalam pakan terhadap pertumbuhan gonad dan pertumbuhan somatik pada ikan nilem. Hal ini dapat dilihat dari persentase pertumbuhan gonad pada perlakuan OMiGH dan OMi lebih tinggi sebesar $73.03 \%$ dan $71,22 \%$ dari total pertambahan bobot ikan. Peningkatan persentase pertumbuhan gonad pada perlakuan $\mathrm{OMiGH}$ dan $\mathrm{OMi}$ diduga disebabkan oleh adanya pengaruh hormon oodev dan nutrisi dari minyak ikan dalam pakan sehingga keseluruhan hasil metabolisme tubuh dimanfaatkan dalam proses perkembangan gonad.

Peningkatan persentase pertumbuhan gonad dipengaruhi oleh kandungan hormon PMSG dan antidopamin yang terdapat dalam hormon Oodev. Pregnant Mare Serum Gonadotropin (PMSG) berfungsi dalam meningkatkan FSH dan LH didalam tubuh ikan, serta mendorong kerja fisiologis yang berporos pada hipotalamus dan pituitari dalam mendukung pematangan gonad (Nagahama, 2008). Sedangkan antidopamin berperan dalam menghambat kerja dopamin sehingga kerja fisiologi kelenjar hipotalamus dalam mensekresi hormon gonadotropin tetap berlangsung (Sudrajat, 2010). Setelah itu, gonadotropin akan merangsang ovarium untuk melakukan proses pematangan telur pada ikan.

Secara alami GH terlibat di dalam pengaturan pertumbuhan somatik dan metabolisme protein, lipid, karbohidrat dan mineral (Bolander, 2004). GH juga mempunyai peranan penting dalam proses reproduksi (Nader et al., 1999). Meningkatnya persentase pertumbuhan gonad pada perlakuan yang dikombinasikan rGH diduga GH mampu menstimulasi sekresi estradiol$17 \beta$ dalam darah sehingga sekresi vitelogenin dalam hati juga meningkat (Singh et al., 1998). Peningkatan vitelogenin menyebabkan proses vitelogenesis dan perkembangan oosit lebih cepat.

Pengaruh penambahan nutrisi pada pakan melalui minyak ikan juga dapat meningkatkan proses percepatan pembentukan telur ikan sehingga dapat meningkatkan meningkatkan persentase gonad didalam tubuh ikan. Menurut Izquierdo et al. (2001) menerangkan bahwa asam lemak essensial yang berperan dalam menutrisi induk ikan serta mempengaruhi penampilan reproduksi ikan baik untuk dalam proses pembentukan telur maupun pematangan gonad. Keberadaan asam lemak essensial pada membran sel juga mempengaruhi sifat fluiditas membran sel yang berfungsi sebagai prekursor senyawa prostaglandin yang berperan sebagai hormon gonadotropin dalam proses pembentukan telur (Djojosoebagio, 1996).

Pengamatan GSI selama penelitian menunjukkan bahwa penambahan kombinasi oodev, minyak ikan, dan hormon rGH $(\mathrm{OMiGH})$ di dalam pakan dapat meningkatkan nilai GSI secara signifikan jika dibandingkan dengan kontrol. Pada Gambar 1 dapat dilihat peningkatan GSI tertinggi hari ke 28 terdapat pada perlakuan OMiGH sebesar $23,56 \%$ dan mengalami penurunan nilai GSI pada hari ke-42. Berdasarkan data tersebut dapat diketahui bahwa proses pematangan gonad yang ditambahkan oodev, minyak ikan dan rGH terjadi dalam kurun waktu 28 hari terlihat dari puncak kurva yang terdapat pada Gambar 1. Rahcman (2013) melaporkan, terjadinya penurunan nilai GSI pada ikan patin (Pangasianodon hypopthalmus) yang ditambahkan hormon PMSG dan antidopamin pada hari ke 56 diakibatkan oleh ikan uji telah mengalami fase vitelegenesis, sehingga aktifitas pertumbuhan oosit berhenti kemudian berganti proses pematangan akhir yang menyebabkan pertumbuhan gonad mulai berkurang.

Akan tetapi pada perlakuan OGH dan kontrol masih mengalami peningkatan nilai GSI sampai pada hari ke-42. Peningkatan nilai GSI pada perlakuan OGH memperlihatkan bahwa perlakuan tersebut masih mengalami proses pematangan akhir. Lambatnya percepatan kenaikan nilai GSI diduga dipengaruhi oleh tidak ketersediaan nutrisi yang cukup bersumber dari minyak ikan seperti pada perlakuan OMiGH dan OMi sehingga menyebabkan puncak peningkatan nilai GSI pada perlakuan OGH terjadi pada hari ke 42.

Fekunditas merupakan jumlah telur yang dihasilkan oleh suatu indukan ikan (butir $\mathrm{kg}^{-1}$ ). Hasil uji statistik menunjukkan bahwa kombinasi oodev, minyak ikan dan rGH pada hari ke 28 berpengaruh nyata terhadap fekunditas dibandingkan dengan kontrol (Gambar 5). Hasil pengamatan fekunditas tertinggi di hari ke 28 terdapat pada perlakuan OMiGH sebesar 290265 butir $\mathrm{kg}^{-1}$. Tingginya 
fekunditas pada perlakuan OMiGH diduga disebabkan oleh ketersedian secara hormonal dan nutrien yang cukup sehingga proses vitelogenesis akan bekerja lebih cepat dalam memproduksi telur. Sesuai penelitian Nainggolan (2014), menyatakan bahwa induksi oodev sebanyak 15 IU dan Spirulina platensis 3\% dapat meningkatkan fekunditas ikan lele (Clarias sp) sebesar 112417 butir. Keong dan Wang (2011) melaporkan dengan penambahan minyak ikan sebesar $9,16 \%$ pada pakan induk ikan nila (O. niloticus) dapat meningkatkan fekunditas telur sebesar $870 \pm 73$ butir ekor ${ }^{-1}$ ikan. Serta penambahan minyak ikan $10 \%$ pada pakan dapat meningkatkan fekunditas telur ikan baung (Ictalurus

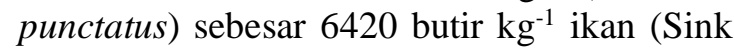
et al., 2010).

Berdasarkan data pada Tabel 2, terlihat pada perlakuan OGH hari ke-28, perlakuan yang tidak ditambahkan minyak ikan dalam pakan cenderung rendah nilai fekunditasnya dibandingkan dengan perlakuan yang ditambahkan minyak ikan. Hal ini disebabkan oleh kekurangan asam lemak essensial yang dibutuhkan oleh ikan pada proses vitelogenesis. Hasil penelitian ini menjelaskan bahwa ketersediaan hormonal dan nutrisi sangat dibutuhkan oleh ikan dalam proses reproduksi.

\section{DAFTAR PUSTAKA}

Achmadi, S.S., 1992, Kimia Organik, Edisi II, Erlangga, Jakarta.

Agus. 2011. Beberapa Metode Pembenihan Ikan Air Tawar. Yogyakarta: Kanisius.

Agus, A. 2001. Aroma terapi. Penerbit Swadaya. Jakarta.

Affandi, R dan Tang, U.M. 2002. Fisiologi Hewan Air. Unri Press. Riau.

Afrianto, E dan E.Liviawaty. 1992. Pengendalian Hama dan Penyakit Ikan. : Penerbit KanasiusYogyakarta.

Amri, K. dan Khairuman. 2002. Menanggulangi Penyakit pada Ikan Mas dan Koi. Agro Media Pustaka. Jakarta.

Arora, D.S. dan Bhardwaj. 1997. Antibacterial Activity of Some Medicinal Plants. Geo. Bioscience, (24): 127- 131.

Austin, B \& D.A. Austin. (1987). Bacterial fish Phatogens; Disease in Farmed and
Wild Fish. Ellis Horwood Limited. Chichester west Sussex, England.

BADAN POM RI. 2013. Jintan Hitam Sebagai Imunostimulan. InfoPOM Vol.14 No. 1 Januari-Februari 2013. Jakarta.

Baratta TM, Dorman DHJ, Deans SG, Figueiredo CA, Barroso JG. 1998. Antimicrobial and Antioxidant Properties of Some Commercial Essential Oils. Journal of Flavour Fragr, 13:44-235.

Barus, W. N. U. 2013. Uji Efektivitas Antibakteri Ekstrak Daun Kamboja (Plumiera rubra) pada Konsentrasi yang Berbeda terhadap Pertumbuhan Aeromonas hydrophila Secara In Vitro. Skripsi. Fakultas Pertanian Universitas Sumatra Utara. Medan.

Bassole IHN, Meda AL, Bayala B, Obame LC, Ilboudo AJ, Franz C, Novak J, Nebie RC and Dicko MH. 2011. Chemical Composition and Antimicrobial Activity of Cymbopogon citratus and Cymbopogon giganteus Essential Oils Alone and in Combination. Journal Phytomedicine, 18 (2011): 1070-1074.

Corbel, M.J. 1975. The immune response in fish: A review. J. Fish Biol., 7: 539563.

Corner, DE. 1995. Naturally Occuring Compounds in Antimicrobial in Food Eds., by Davidson PM and Branen $A L$. $E d s$.Marcel Dekker. New York.

Darmayasa, I.B.C. 2008. Daya Hambat Fraksinasi Ekstrak Sembung Dalan (Sphaerantus indicus L.) Terhadap Bakteri Escherichia coli dan Staphylococus aureus. Jurnal Biologi XI (2) : 74-77.

Effendi, M.I. 1992. Metode Biologi Perikanan, Penerbit Yayasan Agromedia. Bogor.

Fernando, C. F. J.L Furtado, A. V Gussev, G. Honek and S.A. Kakonge. 1972. Methods for the Study of Fresh Water Fish Parasites. University ofWaterloo. Biologi Series: 1-76

Fidyandini, H. P., Subekti, S., dan Kismiyati. 2012. Identifikasi dan Prevalensi Ektoparasit pada Ikan Bandeng (Chanos chanos) yang Dipelihara Di Karamba Jaring Apung Upbl Situbondo Dan Di Tambak Desa Bangunrejo 
Kecamatan Jabon Sidoarjo. Journal of Marine and Coastal Science, 1(2), 91 $112,2012$.

Ganjewala D. Biochemical and molecular characterization ofgeraniol rich lemongrass (Cymbopogon flexuosus Nees exSteud) Wats. Mutant cv. GRL1. 2002 Thesis.

Guffin McM, Hobbs C, Upton R. 1997. American Herbal Products Association Botanical Savety Handbook. Boca Raton, CRC Press.

Gomez, K.A. \& A.A. Gomez. 1995. Statistical Procedures of Agricltural Research 2 Ed. An International Rice Research Institute Book John Willey and Sons. Losbanos.

Hamza, I. S., Sundus H. A., Hussaine A. 2009. Study the Antimocrobial Activity of Lemon Grass Leaf Extracts. 2:1

Hanafiah, K A. 2004. Rancangan Percobaan Teori dan Aplikasi. PT. Raja Grafindo Persada. Jakarta.

Handayani. M. 2015. Aktivitas Antimikroba Ekstrak Kulit Buah Manggis (Garciniamangostana) Terhadap Bakteri Aeromonas hydrophila, Edwardsiella tarda dan Jamur Saprolegnia.sp. Universitas Sumatera Utara. Medan.

Harjadi, 2010. Kandungan kimia batang serai. http://harjadi-pasukan berdarah.blogspot.com. Diakses tanggal 29 April 2016. 